\title{
芳香族アミン曝露に起因する職業性膀胱癌の現状と 今後の問題点についての考察
}

\author{
山 村譲 \\ 産業医科大学産業生態科学研究所環境疫学教室
}

\begin{abstract}
要旨：芳香族アミン類に曝露した労働者に発生する膀胱癌が最初に報告されてから一世紀にな る.この間に主要先進国では発癌性アミン類の製造禁止等の対策がとられ，日本でも昭和 47 年に労働安全衛生法が施行され発癌性アミン類の製造と使用がともに禁止された。最 近の報告では，過去に発癌性アミンに曝露した作業者の膀胱癌発症のリスクは数倍から数 十倍で, 量反応関係の認められる報告が多い. 今後の問題として, benzidine や 2-naphthylamine 以外の芳香族アミンの発癌性, 染料曝露により体内で代謝されて生じる発癌性アミ ン，発展途上国からの輸入製品に含まれる発癌性アミン等がある，また，膀胱癌発生のリ スクが高いと報告された職業は, 化学, 染料工業以外では皮革工業, ゴム工業, 印刷, 織 物，美容，トラック運転等がある。これらの問題を解決するには，疫学や中毒学と臨床医 学その他の分野との協力が不可欠である.
\end{abstract}

(1989 年 8 月 15 日 受付, 1989 年 9 月 11 日 受理)

はじめに

芳香族アミン類への曝露が原因で発生する職業性膀 胱癌は, ドイッの Rehn（1895）により最初に報告さ れたが，その後の染料工業の発展に伴い，イギリス (Wignall, 1929), イタリア (DiMaio, 1937),アメリカ (Gehrmann, 1934; Evans, 1937)，スイス (Müller, 1933），日本（原，1959; 大井田，1957）など各国で 職業性膀胱癌の発生が報告されるようになった。これ らの職業性膀胱癌の原因物質として, 2-naphthylamine （BNA）の発癌性が Hueper \& Wolfe (1938) のイヌを 用いた動物実験で示され，また，イギリスの Case et al. (1954) の疫学調查によって, benzidine (BZ), BNA などの芳香族アミン類の発癌性が疫学的にも証明され た。

日本では，1949年頃，染料製造業者の同業者団体 である化成品工業協会で外国に扔ける芳香族アミンの 発癌性の問題が注目されたことがあるが，1953年か ら 3 年間, 中国への輸出のために BZ の増産が行われ, その生産量は例年の 3 倍に達した. 当時の労働者の 多くは劣悪な作業環境のため, 高濃度 $\mathrm{BZ}$ 曝露を受け
ることとなり，その中から後に多数の職業性膀胱癌が 発症した (Tsuji et al., 1961; 志岐, 1970; 石津, 1973). 化学染料業界では 1960 年頃から化成品工業 協会を中心に対策を検討し始め, 1962 年からパパニ コラ法による尿細胞診をスクリーニングとして取り入 れた管理体制を開始した。また，1972 年の労働安全 衛生法の施行により日本でもBZ, BNA，4-aminobiphenyl，4-nitrobiphenyl の 4 物質の製造，使用，輸 入が禁止され, また, それまでの曝露労働者には退職 時に健康管理手帳を交付し, 生涯を通じての健康管理 が続けられる体制ができた，石津によると，日本で過 去にこれらの物質に曝露した労働者で現在追跡対象と なっている者は 3 千数百名であるが, 現在も毎年数 人から数十人の新規の膀胱癌患者が発生している（石 津, 1988).

このように，染料製造業における芳香族アミン取り 扱いによる職業性膀胱癌はわが国扔よび諸外国の労働 衛生に大きな影響を及ぼして現在に至っているが，他 の産業でもさまざまな経路でこのような芳香族アミン に微量ながら曝露する可能性が指摘され, 種々の職業 で膀胱癌のリスクが高いという疫学調查の結果が報告 
されるなど，未だ解決されない問題も多い.

本論文では，職業性膀胱癌のうち，主に芳香族アミ ン類への曝露によると考えられているものを中心に， 曝露労働者の現況を述べるとともに，各国における最 近の報告から職業性膀胱癌の今後の問題点をあげ，そ れを業種別に膀胱癌発生りスクおよびその要因につい て考察した結果を述べる。

\section{芳香族アミンの発癌性に関する最近の報告から}

最近 10 年間でも，イギリス，アメリカ，イタリア などから，1920 年頃から 1970 年頃までの間に化学 工業，染料工業において BZ B BNA などの芳香族ア ミンに曝露した労働者集団を対象にしたコホート研究 およびケースコントロール研究がいくつか報告されて いる.

Schulte et al. (1985) は，化学工場で BNAに曝露 した 1,385 名の対象者集団を 1940 年から 1982 年ま で追跡し，膀胱癌発症のリスクは一般人口に比べて 4 倍であり，また，同集団のケースコントロール調査の 結果では, 1 年以上曝露した群のリスクは 7 倍であっ たと報告している (Schulte et al., 1986). Meigs et al. （1986）が 984 名の対象者を追跡した調査では，曝露 群の Standardized Incidence Ratio (SIR) は全体で 340 であり，高曝露群では 1,300 ，また 1950 年以前 に曝露した者とそれ以後に曝露した者との比較では, SIR はそれぞれ 980 と 210 であり前者の方が高い值 を示した. Decarli et al. (1985) は芳香族アミン曝露 者の膀胱癌のリスクは一般集団と比較して 46 倍であ り，曝露開始年齢が若いほど相対危険度が高いという 強い負の相関が認められたと報告している. Stern $e t$ al. (1985) は BNA に曝露した対象者 1,300名を追跡 調查し，膀胱癌のリスクは一般人口に比べて 3 倍と 報告した。また，Delzell et al. (1989）は2,600名の 染料工業從事者を追跡した結果，膀胱癌のリスクは最 大で 12 倍であったと報告した. Boyko et al. (1985) は arylamine 曝露歴のある者を対象とした調査で 3 倍の膀胱癌のリスクを認めたと報告した.Vineis \& Magnani (1985) のケースコントロール調査では，染 料工業における膀胱癌リスクは 4 倍であった。また， Risch et al. (1988) はケースコントロール調査を行い, 化学工業, 染料工業従事者で 2 倍から 4 倍のリスク の増加をみたと報告している。

わが国では，Ohkawa et al. （1982）が過去に芳香
族アミンに曝露した集団における職業性膀胱癌の発症 率は 10 万人対 200 人であると報告したが，日本人の 一般の膀胱癌の発生率は男性で 10 万人対 5 人程度で あることを考えるとリスクは 40 倍以上ということに なる，発癌性の強さは一般にBNAの方が BZよりも 強く，潜伏期間も BNA の方がより短いとされてきた が，日本では BZ の方が膀胱癌の発症率が高いという 結果も出て抢り (Ohkawa et al., 1982), この問題の解 決には，なお今後の追跡研究の結果が待たれる。

膀胱癌の発症年齢は曝露開始年齢に関係し, 若年で 曝露を開始した者は発症年齢も若いが，潜伏期間につ いては曝露開始年齢が高いほど短いという結果が報告 されている(中村・他，1980）。また，比較的最近に なってから曝露した例を対象とした調查では観察され たリスクが小さな場合があるが，これは必ずしも最近 の曝露レベルが低いためだけではなく，観察期間が短 期であるため，まだ潜伏期間に達していないことが考 えられるとしている (Stern et al., 1985).

曝露期間の長さによって膀胱癌のリスクに差がみら れることが観察されており（Rubino et al., 1982; Meigs et al., 1986; Schulte et al., 1985), 曝露期間と膀 胱癌発症のリスクとの間の量反応関係が示されている. また一般に製造業務に従事した労働者の方が使用取扱 業務よりリスクが高い傾向があることが観察されてお り，従来の知見と一致している.

BZ B BNA の発癌性が問題になり始めた 1940 年 代頃より各染料工場において各種の曝露防止対策が 実行されたが，その改善策施行の前後で膀胱癌のリス クが大きく変化している (Meigs et al., 1986; Parkes et al., 1982).つまり，1950 年以前に曝露開始した場 合の膀胱癌発症のリスクは，1950年以後に曝露開始 した場合のリスクよりも大きいことが報告されている。

\section{合成染料および BZ, BNA 以外の芳香族アミン}

労働安全衛生法で禁止されている4物質は膀胱に対 する発癌性があることがほぼ確立されているのに対し， 製品である BZ 系アゾ色素については発癌性を示すと いう疫学的デー夕が不十分な状況である. しかし友禅 絵師，染色や織物等の職業に従事する者に膀胱癌発生 率が高いという報告がある（Vineis \& Magnani, 1985; Risch et al., 1988; 吉田・他，1971)。また動物実験で 肝癌が発生したとの報告もあることから〔IARC (International Agency for Research on Cancer), 1987], 
今後さらに疫学的研究を進めていく必要があろう。か つて 1-naphthylamine の発癌性の有無が論議されたこ とがあったが，これは精製技術が不十分なために，不 純物として数\%混在していた BNAの影響によるもの であったと考えられている。同様に各種アゾ色素中に 含有される発癌性不純物の量も，精製技術が良くなる 以前には現在よりも多量であったのが，精製技術の改 良により，それらの濃度は以前よりもかなりの低濃度 になっていると予想される (Dewan et al., 1988).

また，米国をはじめ各国で使用されている多くの合 成色素は 0 -tolidine, 0 -dianisidine や BZ を不純物と して少量含有している (Schulte et al., 1987). Ott \& Langner (1983) は, aniline, o-tolidine, 4-chloroo-toluidine などへの曝露者を対象に調査を行い膀胱癌 の増加は認められないという報告をしているが，これ らの物質はその化学構造が BZ と類似しており，動物 実験において変異原性や膀胱発癌性が報告されている (Pliss \& Zabbzhinsky, 1970; Hadidian et al., 1968; Haley, 1975). Rubino et al. (1982) はマゼンタ（フク シン）製造作業者にも膀胱癌リスクの増加がみられた と報告したが，これは o-toluidine, 2-methylenaniline に曝露するためではないかとしている。これらの物質 は合成染料業界において現在もなお広く使用されてお り，製品である合成染料も他の多くの産業分野で使用 されている.

合成染料そのものは現在のところ発癌性はないと考 えられているが，体内に吸収された合成染料の一部が 腸内細菌や肝臓のミクロゾーム酵素の作用によって分 解されて，もとの原料である芳香族アミンが生成され ることが動物実験で報告されている (Lynn et al., 1980)。また，ある種の BZ 系アゾ染料の曝露を受け た作業者の尿中に BZ 等etylbenzidine が検出され ている (Lowry et al., 1980; Dewan et al., 1988).この ことはこれらの染料に曝露した場合の発癌可能性を示 唆するものである.

BZ 系染料は現在も米国をはじめ多くの国で広く使 用されているが，それらの染料の中で特にその発癌性 が疑われているものは Direct Black 38, Direct Green 1, Direct Red 17, Direct Red 27 の 4 種類である. また, アメリカ合衆国の NIOSH (National Institute for Occupational Safety and Health) が 1978 年に取扱注 意を勧告したものには Direct Black 38, Direct Blue 6, Direct Brown 95 が含まれている (Schulte et al., 1987)。ちなみに現在，米国では1,200種類の染料を
合成し，800 種類の染料を輸入しているといわれる。

\section{染料工業以外の膀胱癌リスクの高い業種}

染料工業以外の業種については，膀胱癌のケースコ ントロール研究で職業別のリスクの分析を行った報告 があり，また，特定の職種に従事する労働者を対象と したコホート調査もある。

Vineis \& Magnani（1985）の報告によると，膀胱癌 発症のリスクの増加が観察された職業は，化学，染料 工業の他には，皮革，ゴム，織物，旋盤工，印刷，卜 ラック運転などであった. Glashan \& Cartwright （1981）执よび Cartwright（1982）の報告によると, 皮革, 美容 (ヘアドレッサー)，印刷，染料使用業の 職種が，また， Risch et al. (1988）の報告では, 化 学, 染料工業以外に, 衣類染色業が, リスクの高い業 種としてあげられている. Sullivan（1982）の報告で は漁業, 水道, 電話, 自動車販売, 靴修理, 建築作業 なども膀胱癌のリスクの高い職種としてあげられてい る. いずれも染料や色素を使用する可能性の高い業種 が多く含まれている.

IARC（1982）によれば BZ は254種類の合成染料 や色素に，またゴムやプラスチックの硬化剂や印刷イ

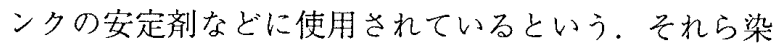
料などの製品は，それ自体は発癌性アミン類を含有し なくても，上述のように，生体内に吸収されたあと分 解代謝されて，もとの BZ などの発癌性アミンを生じ ることが観察されて抢り，その中間代謝物の中にも実 験的に発癌性が認められたものが存在しており (Decoufle, 1979), それらの影響も疑われている.

これらの職業で観察される膀胱癌のリスクは, 増加 が観察された場合も，2 倍から 7 倍程度であるが，こ れらの職種が多岐にわたること，従事人数が多くその 曝露人口も多数にのぼると考えられること，また，こ れらの職業が今後も存続していく職種であると考えら れることからみて，わずかでもリスクの上昇を認めた ことは重要なことである。

\section{1. 皮革工業}

Marrett et al. (1986) は，ケースコントロール調 查を行い, 皮革工業従事者の膀胱癌のオッズ比は 1.4 であり，同じ作業でも 1945 年以前に曝露した場合と， 粉塵に曝露される作業に従事していた場合とで特に高 い膀胱癌リスクが観察されたと報告している。しかし， 
Edling et al. (1986) はスウェーデン最大の皮革工場 が立地する地域でケースコントロール研究を行い, 皮 革なめし作業における膀胱癌のリスクの上昇は認めな かったと報告した。

皮革工業の場合の発癌因子としては, 皮革製品の染 色や仕上げに用いる工業用染料，色素に不純物として 含まれる発癌性芳香族アミン類の可能性が高いという (Marrett et al., 1986). Decoufle (1979) はニュー ヨークの膀胱癌のケースコントロール研究で, 膀胱癌 発症のリスクは，皮革工業従事歴がある場合は男性で 6.3 倍, 女性で 4.4 倍, さらに 5 年間以上の従事歴の ある場合は 11 倍となり, 量反応関係を認めたと報告 している.

\section{2.ゴム工業}

Monson \& Fine（1978）は 14,000名のゴム工業従 事者のコホートを 1940 年から 1976 年まで追跡調査 して最高 2.5 倍の膀胱癌死亡率の増加をみたと報告し た. Checkoway et al. (198I）はケースコントロール 研究を行い, 成形工程や圧搾工程の作業で 2.2 倍の膀 胱癌羅患率の上昇を認めたと報告した。しかし，

Parkes et al. (1982) のコホート調査では 37,000名 の対象者を 1946 年から 1975 年までの間追跡したが 膀胱癌死亡率の増加は観察されず，1951 年以前に曝 露した群でやや死亡率の増加をみたが有意ではなかっ たと報告している. Holmberg et al. (1983) の調査で は 13,000 名のコホートを 1930 年から 1975 年まで 追跡して膀胱癌のリスクは全体で 2.3 倍, タイヤ以外 の部門で 2.5 倍であり, 膀胱癌死亡率の上昇が報告さ れている. しかし, Sorahan et al. (1986; 1989) は ゴム工業従事者に関するコホート調查を行い, 36,000 名の対象者を 1946 年から 1985 年まで追跡 したが，膀胱癌の死亡率の増加は認められず，作業部 門別でも増加はみられなかったと報告している。

ゴム工業におけるこれらの膀胱癌リスク上昇の原因 としては酸化防止剂への曝露が考えられている. 1950 年頃まで使用されていた酸化防止剤には BNA が不純物として含有されていたが，ゴム工業の工程に は加熱操作があり，そこで発生する揮発成分のなかに BNA などの発癌物質が含まれていた可能性が考えら れる，そのほか，不純物として BZ を含む酸化防止剂 も以前は使用されており，1950年以後の曝露につい ては，それ以前に比べて膀胱癌発生のリスクが減少す ることが観察されている（Monson \& Fine, 1978;
Parkes et al., 1982).

今後, 問題となるのは，ひとつは古い夕イヤなどを 再生した場合に製品中に含まれる発癌性物質への曝露 であり，もうひとつは低レベルの発癌性不純物を含む 酸化防止剂への曝露である。後者には，製造工程で用 いられる酸化防止剂の中に不純物として含有される芳 香族アミンのほかに，酸化防止剤の一部が体内で代謝 されてできる芳香族アミンの発癌性の問題が含まれる.

1950 年代以後もBNA 製造していた国は多かっ たし（ちなみに日本と米国は1972 年までは製造し ていた）また，たとえ自国では製造していなくても， それらを使用している国のゴム製品を輸入していれば， それを加工したり再生したりする過程で含有されてい る発癌物質に曝露する可能性がある. 1967 年に制定 されたイギリスの Carcinogenic Substances Regulations は，不純物として含有される BNA は $1 \%$ 以上の ものしか規制の対象にしていない. 酸化防止剤の発癌 性についてはリスクはないとする報告もみられるが, そのような報告をした調査では統計的な検出力が不足 していて，わずかなリスクの上昇を検出できなかった のではないかという疑問も出されている（Wallace, 1988).

また，酸化防止剂として N-phenyl-2-naphthylamine (PBN) と N-phenyl-1-naphthylamine (PAN) \& 1950 年以降使用されてきた。これらの物質はBNAを不純 物として含有するが，その濃度は以前の数百 $\mathrm{ppm} の$ レベルから現在では数 ppm のレベルに下がってきて いる。また，精製技術の向上に伴って，作業環境にお ける現在の BNA の気中濃度は検出限界以下 $(<0.7$ $\left.\mathrm{mg} / \mathrm{m}^{3}\right)$ にまで改善している. PBN はその一部が生体 内で代謝されて BNA を生成すると考えられているが, その曝露推定量から考えて生成される BNAの量が微 量であること，その代謝経路で BNA が生成されるス テージからみて，BNAの最終発癌物質であるとされ る水酸化物まで達することなく排出されると予想され ることから，今のところ，これらの物質への曝露によ る膀胱発癌の可能性は低いとする意見もある（Nutt, 1983).

\section{3. 美容 業}

美容業 (ヘアドレッサー) については, Guberan et al. （1985）の1,370名の対象者を追跡したコホート調査 があり，男性のみに2.6倍の膀胱癌りスクの上昇をみ たと報告しているが，一方， Hartge et al. (1982) の 
報告のように毛髪染料 (ヘアダイ) の使用は膀胱癌発 症のリスクを増加させることはないとするものもあり， 今後，詳細な曝露状況や曝露物質の検討を要すると考 えられる。また, 毛髪染料ではないが, Sole \& Sorahan （1985）は魚釣り歴の有無と膀胱癌りスクの上昇との 間に相関を認め，その要因として釣り餌の染色に用い られるアゾ染料が疑わしいと報告している.

\section{4. プラスチック工業.}

プラスチック工業において近年，成形工程で使用尚 れている MBOCA (4-4-methylenebis, 2-chloroaniline), 4-4-methylene-dianiline $の$ 膀胱発癌性が注 目されてきている。このリスクは 3 倍程度との報告 が出ているが (Rubino et al., 1982), リスクは認めな かったとする報告もある(Lynch et al., 1971).これ らの物質は皮膚から吸収されて尿に排泄されることが 確認されており，動物実験では膀胱に対する発癌性が 観察されている (Stula et al., 1977). NIOSH はこれら の物質を発癌物質に指定すべきであるとしており (Schulte et al., 1987)，また, Ward et al. (1986) は これらの物質に対する生物学的モニタリングの有用性 および注意点について述べている．疫学的な調査は現 在進行中であり，今までのところ信頼できるデータは 得られて抢らず，詳細については今後の研究成果が待 たれるところである。しかし，これらの物質は小規模 の事業所で広範囲に長期間にわたって使用されており， 曝露人口はかなりの数にのぼると考えられるため，発 癌性が確認された場合の影響はかなり大きいものにな ると推察される。

\section{5. トラック運転その他}

トラック轋転やディーゼル機関使用業務に従事する 者に膀胱癌リスクの上昇がみられるという報告がある。 これはディーゼル機関からの排気ガス中に含まれる多 環芳香族炭化水素 (Polycyclic Aromatic Hydrocarbons；PAH）が発癌因子として重要であると考えられ ている (Silverman et al., 1983; Wynder et al., 1985; Smith et al., 1985; Hoar \& Hoover, 1985; Vineis \& Magnani, 1985; Silverman et al., 1986).

また，機械工や旋盤作業者に認められている膀胱癌 リスクの増加については，マシンオイル中に不純物と して含まれている PBN やPAN，さらに微量不純物と して含有される BNA の影響が考えられる. アルミニウム精鍊工業従事者においても膀胱癌リス
クが上昇しているとの報告があり，アルミニウム精錬 工程の初期に発生する $\mathrm{PAH}$ と関連があるのではない かと考えられている (Theriault et al., 1984).

これらの職業の多くは，今後とも社会的に存続して いくものであると考えられる．環境対策が次第に進み， 各業種に㧍いて使用される化学物質は, 不純物濃度が 低くなっていく結果，曝露レベルは現在より低下する と予想されるが，それでも全くゼロになるということ は不可能である。これらの職業に従事する労働者が低 濃度ながら, 発癌物質に曝露する状態は今後も継続し ていくものと考えられる.

\section{職業性膀胱癌の疫学研究の今後の問題点}

$\mathrm{BZ}$ などの芳香族アミンの曝露に起因する膀胱癌は, 曝露から発症まで 10 年から 30 年に及ぶ長い潜伏期 間をもち，曝露を中止したあと長い時間が経ってから 発症すること，曝露期間が短期であっても発症のリス クは高いことなどの疫学的な特徵をもつ（石津， 1975)。今後, 日本に掠いて新規の患者が発生する可 能性は, 曝露歴のある労働者が生存している間はなく ならないが，現在では発癌性アミン類の製造や使用は 禁止されて扔り，従来のような $\mathrm{BZ} や \mathrm{BNA}$ への職業 性の高濃度曝露者が今後新しく発生する可能性はない と考えられる。

膀胱湂のリスクの評洒にSIRや罹患率を用いた調査 が増えているが，この傾向は今後の研究方法を示唆 するものである。スクリーニングで発見された症例は 臨床症状で発見された症例よりも予後が良い，または 平均余命が長いという報告がある(石津，1988; Ellwein et al., 1984; Ohkawa et al., 1982). スクリー ニングの効果はステージ，媣達度，転移などの対象症 例の状態や治療技術などにより異なるため，一概にス クリーニングが予後の改善に効果があるとは結論でき ないが，今までの報告からみるところ，膀胱癌早期発 見のスクリーニングが普及するにつれて，職業性膀胱 癌の治癒率が一般の膀胱癌よりも良くなり，死亡率が 低下してきていることが予想される，そうなると，膀 胱癌死亡率を一般集団と比較しても，必ずしも職業性 曝露による膀胱癌のリスクの上昇を検出できなくなり， 死亡率を指標に用いた方法は発癌性の調査には適さな くなることが考えられる。しかし，罹患率を用いた疫 学調査を実行する場合には，䍜患率を比較するための 対照群となる一般人口や労動人口における膀胱癌の罹 
患率が必要不可欠となる。これらのデータは癌登録制 度や疾病記録制度が完備している地域しか利用するこ とができず，これらのコントロールデータの不足が研 究そのものの障害となる可能性は高い.

今後の問題点として，その他に動物実験上は発癌性 が疑われるが疫学的に確認されていない化学物質への 曝露や，使用開始後間もないために，長期曝露に対す る安全性が確立されていない物質や, 弱い発癌作用を もつ物質などへの曝露の問題があげられる。前述のよ うに精製技術が向上したために，染料やゴムなどの製 品や，製造工程で用いられる酸化防止剤などの物質に 従来，不純物として混入していた $\mathrm{BZ} や \mathrm{BNA}$ 等の発 癌物質の濃度が低くなり，以前に比較して低濃度で長 期にわたる曝露形態になったことも問題になると考え られる。また，過去に扔いて生産され，染料，ゴム製 品や皮革製品などの形で社会にストックあるいは流通 していた製品に含まれる発癌物質に，その再利用，再 生，または処理，廃棄などの工程で再び人間が曝露す ることもあると考えられる。さらに，法的規制のない 発展途上国などの中には，いまだにこれらの発癌物質 を製造しているところが数多く存在することが予想さ れ (Dewan et al, , 1988), 発癌物質そのものの輸入は 禁止されていても，他の化学物質や工業製品の不純物 として他国に持ち达まれる可能性は否定できない。地 球規模でみる限り, 発癌物質への曝露の分布状態が変 わったに過ぎないということもできよう。

低レベル長期曝露の場合, 観察されるリスクは小さ く，その影響を検出するのは困難を伴うことが多く， また，日常生活の上で曝露する可能性のある他の発癌 物質や酒, 煙草, 薬物, さらに職業上曝露する他の化 学物質の背景としての影響も無視できなくなる. 中で も影響が大きいと考えられるものは喫煙であり， Glashan \& Cartwright (1981) おうひび Cartwright （1982）は，喫煙は膀胱癌発生のリスクを 1.8 倍増 加させると報告した. Najem et al. (1982) も契煙に よるリスクは 2.0 倍であったとしており，契煙の影響 を考慮することは膀胱癌の調查の上で重要と考えられ る。ちなみに，タバコを 1 本吸ったときに曝露する BNA の量は $2.2 \times 10^{-8} \mathrm{~g}$ といわれている（Wallace, 1988).これらの要因を研究実施の際に的確に評価し なければ，職業性曝露のリスクが隠ぺいされたり，複 合作用のために見かけ上のリスクが観察されたりする 可能性が出てくる.

低濃度曝露の場合は因果関係の立証が困難であるた
めに，どの程度までの曝露を業務起因性にするのかと いった労災補償上の問題も起きている，さらに，低濃 度曝露のリスクアセスメントが適切なものでない場合, 十分に安全性の評価ができていない代替物質が導入さ れ，別のより大きな問題が生じたりすることもあり得 る、疫学的研究を実施する上で, 実際問題として, 過 去に拈ける低濃度曝露状況を推定することは困難な場 合が多く，さらに職業性膀胱癌の潜伏期間は長期的に わたるため，その間に工場が閉鎖されたり，記録が紛 失したり，記憶が薄れてしまうというような困難を伴 うこともある。そこで，職業性膀胱癌の長期にわたる潜 伏期間を十分に考慮して，临露歴を正確に調査する方 法の確立とともに，曝露状況を的確に表現しうるよう な職業分類とその表現が必要である。また，実際に得 られた情報も利用するための整理がなされていないこ とが多く，職業と曝露因子に関する情報の体系的整理 と管理が望まれる。このような将来の研究遂行上予想 される障害を取り除くため，疫学のみならず臨床医学， 法律, 化学, 中毒学その他の学問分野との協力体制の 確立が必要となると考える。

\section{おわりに}

以上，主に芳香族アミン類に起因すると考えられて いる職業性膀胱癌について最近の報告を中心に述べた。 芳香族アミン類への職業的曝露の問題はかつての製造 過程における高濃度曝露から，製品中に含まれる不純 物や代謝産物などへの低濃度で比較的長期間の曝露へ とその形態が移っているといえる。また，発癌物質の 製造も先進国から発展途上国へと移っていっており， さらに, 染料工業や化学工業の他にもいろいろな職業 でリスクの上昇が報告されているなど，まだまだ問題 は解決したとはいえないと考えられる。

曝露労働者は過去にわずか数力月の曝露を受けただ けでも，一生涯にわたって膀胱癌発症の危険に悩まさ れる. そのうちの幾人かは実際に発症し，一旦治療が 成功しても再発する可能性が高い。職業癌は人の心身 両面にわたり，大きな苦痛と負担を鱼わせるものであ るといえる。それらをふまえて，疫学的，中毒学的研 究による予防対策とともに，不幸にも過去に発癌物質 に曝露した一人一人の労働者に対する早期発見，早期 治療のための健康管理の体制作りなど，臨床サイドを 含めた支援システムの充実が今後とも一層望まれると ころであろう。 
謝

辞

この総説をまとめるにあたって，ご指導とご校閲を
戴いた産業医科大学産業生態科学研究所環境疫学教室 の大久保利晃教授ならびに山口直人助教授に深謝する.

\section{引用文 献}

Boyko, R. W., Cartwright, R. A., Chir, B. et al. (1985): Bladder cancer in dye manufacturing workers. J. Occup. Med., 27: 799-803.

Cartwright, R. (1982): Occupational bladder cancer and cigarette smoking in West Yorkshire. Scand. J. Work Environ. Health, 8 (Supple. 1): 79-82.

Case, R. A. M., Hosker, M. E., McDonald, D. F. et al. (1954): Tumours of the urinary bladder in workmen engaged in the manufacture and use of certain dyestuff intermediates in the British chemical industry. Part. I. Br. J. Ind. Med., 11: 75-104.

Checkoway, H., Smith, A. H., McMichael, A. J. et al. (1981): A case-control study of bladder cancer in the United States rubber and tyre industry. Br. J. Ind. Med., 38: 240-246.

Decarli, A., Peto, J., Piolatto, G. et al. (1985): Bladder cancer mortality of workers exposed to aromatic amines: Analysis of models of carcinogenesis. Br. J. Cancer, 51: 707-712.

Decoufle, P. (1979): Cancer risks associated with employment in the leather and leather products industry. Arch. Env. Health, 34: 33-37.

Delzell, E., Macauluso, M. \& Cole, P. (1989): A follow-up study of workers at a dye and resin manufacturing plant. J. Occup. Med., 31: 273-278.

Dewan, A., Jani, J. P., Patel, J. S. et al. (1988): Benzidine and its acetylated metabolites in the urine of workers ex posed to Direct Black 38. Arch. Env. Health, 43: 269-272.

DiMaio. (1937): Tumori e lesioni precancerose della vescica da amine o nitroderivati. Arch. Ital. Uro., 14: 283385.

Edling, C., Kling, H., Flodin, U. et al. (1986): Cancer mortality among leather tanners. Br. J. Ind. Med., 43: 494496.

Ellwein, L. B., Farrow, G. M., Friedell, G. H. et al. (1984): An assessment of the impact of urine cytology screening using a computer-based model of bladder cancer. Urol. Clin. North Am., 11: 585.

Evans, E. E. (1937): Causative agents and protective measures in the anilin tumor of the bladder. J. Urol., 38 : $242-250$.

Gehrmann, G. H. (1934): The carcinogenic agent-chemistry and industrial aspects. J. Urol., 31: 126-137.

Glashan, R. W. \& Cartwright, R. A. (1981): Occupational bladder cancer and cigarette smoking in West Yorkshire. Br. J. Urol., 53: 602-604.

Guberan, E. G., Raymond, L. \& Sweetman, P. M. (1985): Increased risk for male bladder cancer among a cohort of male and female hairdressers from Geneva. Int. J. Epidemiol., 14: 549-554.

Hadidian, Z., Fredrickson, T. N., Weisburger, E. K. et al. (1968): Tests for chemical carcinogens. Report on the activity of derivatives of aromatic amines, nitrosamines, quinolines, nitroalkanes, amides epoxides, aziridines and prine antimetabolites. J. Natl. Cancer Inst., 41: 985.

Haley, T. J. (1975): Benzidine revisited: A review of the literature and problems associated with the use of benzidine and its congeners. Clin. Toxicol., 8: 13.

原 一郎 (1959): ある工場でのベンジジン中毒についての研究. 労働科学季報, 7 (1-4 合併号): 39-47.

Hartge, P., Hoover, R., Altman, R. et al. (1982): Use of hair dyes and risk of bladder cancer. Cancer Res., 42: $4784-4787$.

Hoar, S. K. \& Hoover, R. (1985): Truck driving and bladder cancer mortality in rural New England. J. Natl. Cancer Inst., 74: 771-774.

Holmberg, B., Westerholm, P., Maasing, R. et al. (1983): Retrospective cohort study of two plants in the Swedish rubber industry. $\quad$ Scand. J. Work Environ. Health, 9 (Supple. 2): 59-68. 
Hueper, W. C. \& Wolfe, H. D. (1938): Experimental production of bladder tumours in dogs by administration of beta-naphthylamine. J. Industr. Hyg. Toxicol., 20: 46-84.

IARC (1982): Monographs on the Evaluation of the Carcinogenic Risk of Chemicals to Man. Vol. 29, pp. 149183.

IARC (1987): Monographs on the Evaluation of Carcinogenic Risks to Humans. Suppl. 7, pp. 123-263.

:石津澄子 (1973): 職業性膀胱がん． 東女医大誌，43: 339-347.

石津澄子 (1975): 尿細胞診による職業性膀胱性腫瘍の管理. 化成品工業協会, 東京. pp. 1-15.

石津澄子 (1988): 職業性膀胱癌の歴史と展望. 日災医誌, 36: 356-360.

Lowry, L. K., Tolos, W. P., Boeniger, M. F. et al. (1980): Chemical monitoring of urine from workers potentially exposed to benzidine-derived azo dyes. Toxicol. Lett. 7: 29-36.

Lynch, A. L., O'Connor, G. B., Barnes, J. R. et al. (1971): Methylene-bis-ortho-chloroaniline (MOCA): evaluation of the hazards and exposure control. Am. Ind. Hyg. Assoc. J., 32: 802-819.

Lynn, R. K., Donielson, D. W., Ilias, A. M. et al. (1980): Metabolism of bisazophenyl dyes derived from benzidine, 3,3-dimethylbenzidine or 3,3-dimethoxybenzidine to carcinogenic aromatic amines in the dog and rat. Toxicol. Appl. Pharmacol., 56: 248-258.

Marrett. L. D., Hartge, P. \& Meigs, J. W. (1986): Bladder cancer and occupational exposure to leather. Br. J. Ind. Med., 43: 96-100.

Meigs, J. W., Marrett, L. D., Ulrich. F. U. et al. (1986): Bladder tumor incidence among workers exposed to benzidine: A thirty-year follow-up. J. Natl. Cancer Inst., 76: 1-8.

Monson, R. R. \& Fine, L. J. (1978): Cancer mortality and morbidity among rubber workers. J. Natl. Cancer Inst., 61: $1047-1053$.

Müller, A. (1933): Blasenveränderungen durch Amine, Erfahrungen aus dem Industriegebiet Basel. Z. Urol. Chir., 36: 202-219.

Najem, G. R., Louria, D. B., Seebode, J. J. et al. (1982): Life time occupation, smoking, caffeine, saccharine, hair dyes and bladder carcinogenesis. Int. J. Epidemiol. 11: 212-217.

中村 順・高松正人・土居 淳・他 (1980): 和歌山市に掞ける職業性尿路腫痬に関する臨床的検討. 日泌尿会 誌, 71: 945-951.

Nutt, A. (1983): Rubber work and cancer. Scand. J. Work Environ. Health, 9 (Supple): 49-57.

大井田修 (1957): 急性乃至垔急性中毒に関する研究, 1) 実態調査成績. 労働科学, 33: 939-951.

Ohkawa, T., Fujinaga, T., Doi, J. et al. (1982): Clinical study on occupational uroepithelial cancer in Wakayama City. J. Urol., 128: 520-523.

Ott, M. G. \& Langner, R. R. (1983): A mortality survey of men engaged in the manufacture of organic dyes. J. Occup. Med., 25: 763-768.

Parkes, H. G., Veys, C. A., Waterhouse, J. A. H. et al. (1982): Cancer mortality in the British rubber industry. Br. J. Ind. Med., 39: 209-220.

Pliss, G. B. \& Zabbzhinsky, M. A. (1970): Carcinogenic properties of orthotolidine (3,3-dimethylbenzidine). J. Natl. Cancer Inst., 45: 283-289.

Rehn, L. (1895): Blasengeschwülste bei Anilinarbeiten. Arch. Klin. Chir., 50: 588-600.

Risch, H. A. Burch, J. D., Miller, A. B. et al. (1988): Occupational factors and the incidence of cancer of the bladder in Canada. Br. J. Ind. Med., 45: 361-367.

Rubino, G. F., Scansetti, G., Piolatto, G. et al. (1982): The carcinogenic effect of aromatic amines: An epidemiological study on the role of $o$-toluidine and 4,4-methylene bis (2-methylaniline) in inducing bladder cancer in man. Env. Res., 27: 241-254.

Schulte, P. A., Ringen, K., Hemstreet, G. P. et al. (1985): Risk assessment of a cohort exposed to aromatic amines. J. Occup. Med., 27: 115-121.

Schulte, P. A., Ringen, K., Hemstreet, G. P. et al. (1986): Risk factors for bladder cancer in a cohort exposed to aromatic amines. Cancer, 58: 2156-2162.

Schulte, P. A., Ringen, K., Hemstreet, G. P. et al. (1987): Occupational cancer of the urinary tract. In: Occupational Medicine: State of the Art Reviews, Vol. 2, No. 1. (Brandt-Rauf, P. W., ed.). Hanley \& Belfus, Inc., Phil- 
adelphia. pp. 85-107.

志岐太一郎 (1970): Benzidine による職業性尿素路系腫瘍の発生に関する労㗢衛生学的研究. 久留米医会誌, 33: $363-385$.

Silverman, D. T., Hoover, R. N., Albert, S. et al. (1983): Occupation and cancer of the lower urinary tract in Detroit. J. Natl. Cancer Inst., 70: 237-245.

Silverman, D. T., Hoover, R. N., Mason, T. J. et al. (1986): Motor exhaust-related occupations and bladder cancer. Cancer Res., 46: 2113-2116.

Smith, E. M., Miller, E. R., Woolson, R. F. et al. (1985): Bladder cancer risk among auto and mechanics and chemically related occupations. Am. J. Public Health, 75: 881-883.

Sole, G. \& Sorahan, T. (1985): Coarse fishing and risk of urothelial cancer. Lancet, 29: 1477-1479.

Sorahan, T., Parkes, H. G., Veys, C. A. et al. (1986): Cancer mortality in the British rubber industry 1946-80. Br. J. Ind. Med., 43: 363-373.

Sorahan, T., Parkes, H. G., Veys, C. A. et al. (1989): Mortality in the British rubber industry 1946-85. Br. J. Ind. Med., 46: 1-11.

Stern, F. B., Murthy, L. I., Beaumont, J. J. et al. (1985): Notification and assessment for bladder cancer of a cohort exposed to aromatic amines. J. Occup. Med., 27: 495-500.

Stula, E. F., Barnes, J. R., Sherman, H. et al. (1977): Urinary bladder tumours in dogs from 4,4-methylene-bis (2chloroaniline) (MOCA). J. Environ. Path. Toxicol., 1: 31-50.

Sullivan, J. W. (1982): Epidemiologic survey of bladder cancer in greater New Orleans. J. Urol., 128: $281-283$.

Theriault, G., Tremblay, C., Cordier, S. et al. (1984): Bladder cancer in the aluminium industry. Lancet, 28: $450-497$.

Tsuji, I., Kuroda, K., Nakajima, F. et al. (1961): Mortality and clinical statistics of bladder tumours in Japan; Occupational bladder tumours in Japan. Jap. J. Cancer Clin., 7: 347-355.

Vineis, P. \& Magnani, C. (1985): Occupation and bladder cancer in males: a case-control study. Int. J. Cancer, 35: 599-606

Wallace, D. M. A. (1988): Occupational urothelial cancer. Br. J. Urol., 61: 175-182.

Ward, E., Clapp, D., Tolos, W. et al. (1986): Efficacy of urinary monitoring for 4,4-methylenebis (2chloroaniline). J. Occup. Med., 28: 637-642.

Wignall, A. (1929): Industrial diseases affecting the bladder. Br. Med. J., 2: 291-293.

Wynder, E. L., Dieck, G. S., Hall, N. E. L. et al. (1985): A case-control study of diesel exhaust and bladder cancer. Env. Res., 37: 475-489.

吉田 修・原田 卓・宮川美栄子・他 (1971): 染色作業従事者の膀胱癌一京都府を中心とした疫学調査. 医学 のあゆみ, 79: 421-422. 


\section{Present Aspects and Problems Regarding Occupational Bladder Cancer Due to Expo- sure to Aromatic Amines}

Joe YAMAMURA

Department of Environmental Epidemiology, Institute of Industrial Ecological Sciences, University of Occupational and Environmental Health, Japan. Kitakyushu 807, Japan

Abstract : About a century has passed since the first case of bladder cancer due to occupational exposure to carcinogenic aromatic amines was reported. In the major developed countries of the world, it is forbidden to manufacture and/or to use such aromatic amines. In Japan in the 1950's, many workers were exposed to carcinogenic aromatic amines, but in 1972, the Labor Safety and Health Act came into force and manufacturing and/or using of four kinds of aromatic amines were forbidden. Recently it has been reported that the risk of bladder cancer in workers exposed to aromatic amines before the ban of these chemicals is approximately from several times to a hundred times compared with the general population, and some reports say that dose-response relationship was observed. The important issues now are the carcinogenecity of other kinds of aromatic amines besides benzidine and 2-naphthylamine, carcinogenecity of metabolites of several substances like synthetic dyes, and carcinogenic aromatic amines as impurities in substances imported from developing countries. The type of exposure to these carcinogens changes low level and long period exposures. In addition to the chemical or dye industries, an increased risk of bladder cancer was observed among workers handling leather and rubber and those engaged in printing, textile industries, hairdressing, truck driving and so on. In the future, it will be necessary to cooperate with the departments of epidemiology, toxicology and clinical medicine for the purpose of estimating the risk of these occupations and the health care administration of the exposed workers.

Key words: bladder cancer, occupational, aromatic amines, benzidine, epidemiology.

J. UOEH, 11 (4): 495-504 (1989) 